\title{
Mimari Tasarım Bürolarında Çalışan Mimarların Mesleki Tükenmişlik Düzeylerini Etkileyen Demotivasyon Faktörleri
}

\author{
Tülay Çivící ${ }^{* 1}$ \\ ${ }^{1}$ Balıkesir Üniversitesi, Mühendislik Mimarlık Fakültesi, Mimarlık Bölümü, Balıkesir
}

Geliş tarihi: 27.01.2016 Kabul tarihi: 25.04.2016

\section{Özet}

Bu çalışmada demotivasyon faktörlerinin tükenmişlik düzeyleri üzerindeki etkileri incelenmiştir. Çalışma kapsamında, Maslach Tükenmişlik Ölçeği ve Oyedele [14] tarafından geliştirilen, demotivasyon faktörleri kullanılarak kuramsal bir model geliştirilmiştir. Bu kuramsal model, demotivasyon faktörlerinin tükenmişlik etkisinin olduğunu önermektedir. Kuramsal modelin ileri sürdüğü önermeler, Türk inşaat sektöründe faaliyet gösteren mimari tasarım bürolarında çalışan 148 mimar üzerinde yapılan anket çalışmasıyla mimarların mesleki tükenmişlik düzeylerini etkileyen demotivasyon faktörleri ampirik olarak test edilmiştir. Kuramsal modelin parametrelerinin test edilmesi için yapısal denklem modeli kullanılmıştır. Araştırma sonuçları; mimarların duygusal tükenme düzeylerinin, kişisel başarıda azalma ve duyarsızlaşma düzeylerine göre yüksek olduğu yönündedir. Ayrıca tükenmişlik üzerinde ağırlıklı olarak proje ile ilgili demotivasyon faktörlerinin etkili olduğunu göstermektedir.

Anahtar Kelimeler: Tükenmişlik, Demotivasyon, Yapısal denklem modeli

\section{Demotivation Factors on the Job Burnout Levels that Affect the Architects who Work in Architectural Design Firms}

\begin{abstract}
This study explores factors that burnout influenced demotivating factors. A conceptual model is developed that builds on Maslach bunout inventory and demotivating factors that are used which is written by Oyedele [14]. The conceptual model proposes that demotivating factors affected burnout. These propositions were empirical tested by a survey of 148 architectural design firms. Structural equation modeling was used to estimate the parameters of conceptual models. The research findings reveal that the architect of emotional exhaustion are higher than depersonalization and diminised personal accomplishment. Research finding also indicate that demotivating factors related to the Project influenced burnout.
\end{abstract}

Keywords: Burnout, Demotivation, Structural equation model

\footnotetext{
* Yazışmaların yapılacağı yazar: Tülay Çìi̇Ċ, Balıkesir Üniversitesi, Mühendislik Mimarlık Fakültesi, MimarlıkBölümü, tulay@balikesir.edu.tr
} 


\section{GíRis}

Eski çağlardan bugüne etkinlik gösteren mimar, inşaat sektöründe yapının çeşitli ölçeklerde biçim ve fonksiyon tasarımı (kentsel tasarım, mimari tasarım, restorasyon, restitüsyon, röleve), yapım yönetimi, şantiye organizasyonu, gibi mesleki hizmet alanlarında önemli görev ve mesleki sorumluluklar üstlenmektedir. Birçok katılımcının (kullanıc1, mal sahibi, mühendis, yüklenici, alt yükleniciler, malzeme sağlayıcılar, vb.) yer aldığ karmaşık bir çalışma ortamında meslek pratiklerini (öntasarım, tasarım, yapım, vb.) gerçekleştirmektedir [1]. Mesleğin kendine özgü gereksinimleri ve sorumlulukları, çalışma ortamı, mimarlar üzerinde olumsuz etkiler bırakmaktadır. Bu etkilerden biri de tükenmişlik sendromudur [2].

Tükenmişlik kavramından ilk kez Graham Greene (1961)'nin, “Bir Tükenmişlik Olayı” adlı eserinde söz edilmiştir. Bir mimarın Avrupa'daki yaşamını bırakıp Afrika ormanlarına kaçışı anlatılan romanda, kahraman, aşırı bitkindir ve işi için hissettiği öfke duygusu ile birlikte idealizmini de kaybetmiştir [5].

Tükenmişlik sendromu Maslach ve Jackson [6] tarafından; "işi gereği yoğun duygusal taleplere maruz kalan ve sürekli diğer insanlarla yüz yüze çalışmak durumunda olan kişilerde görülen fiziksel bitkinlik, uzun süreli yorgunluk, çaresizlik ve umutsuzluk duygularının, yapılan işe, hayata ve diğer insanlara karşı olumsuz tutumlarla yansıması ile oluşan bir sendrom" olarak tanımlamıştır. Leiter ve Maslach [3]'a göre tükenmişlik, özellikle hizmet sektörü çalışanların karşılaştıkları çalışma koşullarından kaynaklanan insan üzerinde olumsuz etkiler birakan psikolojik zararlardan biridir.

Tükenmişlik kavramının literatürde incelenmesinde rol oynayan çalışmalardan biri Maslach tarafindan geliştirilen Maslach Tükenmişlik Ölçeğidir [6]. Maslach Tükenmişlik Ölçeği tükenmişliği duygusal tükenme, duyarsızlaşma, kişisel başarıda azalma olmak üzere üç düzeyde ölçmektedir. Yapılan çalışmalarda genel olarak tükenmişlik düzeyleri ve tükenmişlik düzeyine etki eden faktörler incelenmiştir $[4,6,7,8,9,10]$. Tükenmişlik üzerindeki etkisi sıklıkla incelenen kavramlardan biri de motivasyondur [10]. Çalışmalar, çalışma ortamında motivasyonu düşük bireylerle çalışılması veya motivasyonun sağlanamaması halinde bireyin tükenmişlik yaşanması olasılığının yükseldiğini göstermektedir [6, 8, 9, 11, 12, 13].

Bu çalışmada, tükenmişlik üzerinde demotivasyon faktörlerinin etkisinin incelenmesi amaçlanmıştır. $\mathrm{Bu}$ amaç için; Türk inşaat sektöründe faaliyet gösteren, mimari tasarım bürolarında çalışan mimarlar çalışmanın hedef kitlesini oluşturmuştur. İlk aşamada mimari tasarım bürolarında çalışan mimarların tükenmişlik düzeylerinin belirlenmesi, tükenmişlik düzeyleri ve demotivasyon faktörleri arasında herhangi bir etkileşim olup olmadığ 1 ortaya konulmaya çalışılmıştır. Sonraki aşamada, mimarların tükenmişlik düzeyleri üzerinde demotivasyon faktörlerinin etki düzeyi incelenmiştir. Çalışmada tükenmişlik düzeyinin belirlenmesinde Maslach Tükenmişlik Ölçeği kullanılmıştır. Tükenmişlik düzeyine etki eden demotivasyon faktörleri için, Oyedele [14]'in çalışmasından yararlanılmıştır. Demotivasyon faktörleri Oyedele [14]'in çalışmasında yer aldığı gibi, proje ile ilgili faktörler, tasarım ekibi ile ilgili faktörler ve organizasyon ile ilgili faktörler, olmak üzere üç başlık altında ele alınmıştır. [14, 15].

\section{TÜKENMISSLIK VE MASLACH TÜKENMISSLLIK ÖLÇEĞİ}

Tükenmişlik kavramı, ilk ortaya konulduğundan bugüne kadar üzerinde pek çok araştırma yapılmış, tanımlar geliştirilmiştir. Tükenmişlik çalışma ortamında yaşanan stresin ortadan kaldırılmaması sonucu fiziksel sonuçlar da yaratabilen bir sorundur [16]. Maslach [7]'a göre tükenmişlik, çalışma ortamında karşılaşılan stres faktörlerine karşı psikolojik tepkidir. Freudenberger [17], bireyin tükenmişliğinde başarısız olma düşüncesi, doyuma ulaşmayan beklentileri, vb. gibi 
nedenlerin etkili olabileceğini öne sürmüş, çalışma hayatını olumsuz etkileyen bir unsur olarak nitelendirmiştir [17].

Tükenmişliğin yaşanmasında temelde iki faktörün etkili olduğu görülmektedir [17]. İlki bireysel özelliklerdir [16]. Bireysel özelliklerden yaş, eğitim, cinsiyet, medeni durum, işe bağımlılık, motivasyon, iş dişı yaşamdaki stresler, gerçekçi olmayan beklenti ve hedefler, yaşamını değiştirebilecek olaylar üzerindeki kontrolünün az olması, diş denetim yoğunluğu, üstlerinden gördüğü destek düzeyi, iş doyumu, dış kontrol odaklı olma, bireyin kendisini işiyle ilgili yetersiz hissetmesi, empati kuramama, vb. tükenmişlik üzerine etkili faktörlerdendir $[16,18,19,20]$. İkincisi ise çalışma koşulları ve çevresinden kaynaklanan faktörlerdir [16]. Bunlar arasında; çalışma ortamı ve mesleğin kendine özgü özellikleri, yapılan işin niteliği, organizasyonun tipi ve özelliği, iş yükü, iş gerilimi, rol belirsizliği, çalışma zamanı, organizasyonda alınan kararlara katılım, müşteri ilişkileri, yetersiz personel ve teknik donanım, ekonomik ve toplumsal nedenler, aidiyet, ödüller, adalet ve değerler, ilerleme fırsatları, rol çatışması ve belirsizliği, geri bildirim eksikliği, meslekte çalışma süresi, iş yerinde cinsel/duygusal taciz, iş güvenliği, iletişim, vb. faktörleri yer almaktadır [16, 18, 19, 20].

Bireylerin, gerek bireysel özellikleri gerekse çalışma koşulları ve çevresinden kaynaklanan sorunlara tepki düzeyleri farklılık göstermektedir. $\mathrm{Bu}$ farklılıkları açıklamak üzere geliştirilen en yaygın modellerden biri de Maslach Tükenmişlik Ölçeğidir [6, 21, 22]. Maslach Tükenmişlik Ölçeği üç düzey ile tanımlamıştır. Bunlar; (1) duygusal tükenme (emotional exhaustion), (2) duyarsızlaşma (depersonalization) ve (3) kişisel başarıda azalma (personal accomplishment) [22].

\subsection{Duygusal Tükenme}

Duygusal tükenme, tükenmişlik durumunun ilk ve en önemli aşamasıdır. Yoğun bir çalışma temposu duygusal tükenmenin zemini için uygun ortam hazırlamakta, bireyin kendini hem duygusal açıdan, hem psikolojik açıdan bitkin ve yorgun hissetmesine neden olmaktadır. Diğer insanların duygusal beklentileri karşısında bu beklentilere karşılık verebilmek için aşırı performans göstermekte, bir zaman sonra beklentilere cevap veremeyecek duruma gelmektedir [6]. Bu durum bireyin psikolojik olarak duygusal kaynaklarının giderek azaldığını hissetmesine neden olmaktadır. $\mathrm{Bu}$ durumdaki birey çevresine fayda sağlayacak durumda değildir, aksine üzerinde hissettiği duygusal yükü hafifletmek için birçok kaçıŞ yoluna başvurabilmekte insanlarla olan ilişkilerini en aza indirmektedir [23]. Halbesleben ve Bowler [24], çalışmasında iş performansı üzerinde etkili olan motivasyon gibi psikososyal kaynakların, dolaylı olarak da duygusal tükenmeye zemin hazırlayabileceğini öne sürmektedir.

\subsection{Duyarsızlașma}

Maslach'a [6, 7] göre duyarsızlaşma tükenmişliğin en problemli boyutudur. Duyarsızlaşma, yoğun iş temposu içinde bireyin işi ile ilgili idealinin kaybolmasiyla kendini hissettirmektedir. Birey, kendini güçsüz ve yetersiz görmesi sonucu çevresinden kaçış yoluna gitmekte, diğer bireylere karşı bir duvar örmeye başlamaktadır. Karşısındakine kaba davranışlar, aşağılayıcı konuşmalar, vb. olumsuz tutumlar sergileyen birey ilişkilerini en aza indirmekte, çevresine karş1 tahammülsüzleşmekte, soğuk davranışlar göstermekte, duyarsızlaşmaya başlamaktadır $[6,25,2]$.

\subsection{Kişisel Başarıda Azalma}

Kişisel başarıda azalma, bireyin kendini işi veya mesleği konusunda yetersiz ve başarısız olarak görmesidir. Birey artık çevresine yeterli gelemediğini, çevresine yarar sağlayamayacağını, başarısız olduğunu düşünür. Kendisi hakkında başarısız hükmünü veren birey özsaygısını yitirmiştir [25]. $\mathrm{Bu}$ aşamada bulunan birey, tükenmişlik içerisine girmiş demektir. Maslach Tükenmişlik Ölçeği farklı alanda çalışmalarda araştırmacılar tarafindan kullanılmıştır [26, 27]. İnşaat sektörü kapsamında yapılan çalışmalar, tükenmişliğin farklı düzeylerde yaşandığını 
göstermektedir. Tükenmişliğin farklı düzeyde yaşanmasında çalışma koşullarının önemini vurgulanmıştır. İnşaat sektöründe çalışma koşullarının büro ve şantiye ortamına göre farklılık gösterdiği, şantiyede çalışanlarının büro çalışanlarına göre tükenmişliklerinin yüksek olduğunu ileri sürmektedir. Bulgular, özellikle şantiye çalışanlarının duygusal tükenme ve duyarsızlaşama düzeyinde tükenmişlik yaşadığını göstermektedir [26-28]. Lingard [26], inşaat sektöründe tükenmişlik kavramını incelediği çalışmasında, meslek profesyonellerinin aldıkları eğitim ile meslek pratikleri arasındaki farkın tükenmişlik düzeyini etkilediğini savunmaktadır. Çelik ve arkadaşları [29, 30] çalışmalarında, mimarlık öğrencilerinin tükenmişlik düzeylerini incelemiş tükenmişlik düzeyinin düşük olduğu, bunun nedeninin çok yönlü disiplin olması, proje ağırlıklı derslerin her dönem farlı konulu tasarım sürecini içermesi, farklı grup öğretim üyeleri ile çalışılmasının öğrencileri monoton bir yapıdan uzaklaştırdığııı savunmaktadır.

\section{MOTIVASYON VE DEMOTIVASYON KAVRAMLARI}

Motivasyon, bireyin organizasyon içinde davranışlarından, çalışma yaşamındaki performanslarına kadar etkili olan faktörlerden biridir [31-33]. Maslow'a göre, bireyin motivasyonunda, güven, ait olma, başarı temel gereksinimlerdendir. $\mathrm{Bu}$ gereksinimler kendi içinde bir sıra izlemektedir. Maslow, doyurulan bir ihtiyacın motive edici etkisini yitireceğini öne sürmektedir [34]. McClelland'a göre motivasyon için başarma, bağlanma ve güç ihtiyaçlarının karşılanması gerekmektedir [35]. Herzberg'e göre organizasyonda motivasyon faktörleri (çalışma koşulları, iş güvenliği, başarı, tanınma, sorumluluk alma, yükselme olanağı, işin doğası, vb.), bireyin iş başarısı, iş tatmini ve gelişme ile doğrudan ilişkisi bulunmaktadır [15].

Motivasyon faktörlerinin eksikliği, iş yaşamında birey için itici bir gücün, sosyal bir uyarıcının olmaması anlamına gelmektedir. Motivasyon eksikliği yaşayan çalışanların davranışları, işe karşı ilgisizlik, zamanı boşa harcama ve devamsızlık, problem çözümünün zorluğunun abartılması, tartışma ve şikayetler, problem ve zorluklarla baş etmek için gerekli işbirliğinde eksiklik, değişime karşı direnme olarak ortaya çıkmaktadır [36]. Bu durum demotivasyon olarak tanımlanmaktadır. Kisaca demotivasyon, motivasyonun sağlanmasında etkili olan faktörlerin eksikliği veya var olan motivasyonun kaybedilmesidir.

Motivasyon faktörlerinin bulunması durumunda bireylerin çalışma arzusu artmaktadır. Demotivasyon faktörlerinin varlığında ise işe karşı ilginin ve coşkunun eksikliği veya ortadan kalkması, hayal kırıklığı, işe bağlılığın düşmesi, çalışmamak için söylenme, bireylerin sosyal yaşamında değişiklik, iş başarısının düşmesi, iş tatminsizliği, stres, tükenmişlik vb. gibi belirtiler gösterebilmektedir.

Motivasyon ve demotivasyon kavramı ulusal ve uluslararas1 literatürde incelenmiştir $[14,15$, 31-33]. Motivasyon ve demotivasyon faktörleri inşaat sektörü içinde önem taşımaktadır. $\mathrm{Ng}$ vd. [28], inşaat sektöründe proje takımının iletişim ve koordinasyon zayıflığı, takım çalışma arkadaşları arasındaki uyumsuzluk gibi faktörlerin performans1 etkileyen demotivasyon faktörlerinden olduğunu öne sürmektedir. Oyedele [14] çalışmasında, mimarların çalışma koşullarından kaynaklanan demotivasyon faktörlerini üç başlık altında incelemiştir: (1) proje ile ilgili demotivasyon faktörleri; işverenin kendine has (tanımsız, mantıksız, net olmayan) proje talepleri ve amaçlarının bulunması ve bu taleplerin neden olduğu proje üzerindeki sık yapılan tasarıma yönelik değişiklikler, uzun ve yorucu çalışma saatleri, işveren proje ekibi arasındaki uyumsuzluk, mimarın mesleki gelişimine katkısı olmayan projeler, yetersiz teknolojik donanımlar, (2) tasarım ekibiyle ilgili demotivasyon faktörleri, tasarım ekibi arasındaki yetersiz iletişim, koordinasyon, rekabet, işbirliği, takım üyelerinin eşit sorunluluk bilincini taşımaması, cinsiyet ayrımcıllğgı, (3) organizasyon ile ilgili demotivasyon faktörleri ise; yetersiz iş güvencesi, maaş ve prim, kariyer gelişimi ve terfi, kurumsal ödüllendirme, yöneticinin çalş̧anlara olumsuz tutumları (zorbalık, diktatörlük, vb), adaletsizlik, çalışan- iş görevleri uyumunun sağlanamaması, 
çalışma ortamının olumsuz koşulları (kalabalık, ses, vb), olumsuz eleştiriler, aşırı iş yükü, kurumsal planlama ve kontrol yetersizliği, karar verme sürecine katılımın düşük olması ve çalışanların fikirlerine önem verilmemesi, olarak tanımlamıştır [14, 15]. Ünlü [15] çalışmasında, Oyedele [14] tarafından yapılan çalışmanın ülkemiz mimarlık meslek pratiği için incelemiş, mimarların en çok organizasyon ile ilgili demotivasyon faktörlerinden etkilendiğini, en önemli demotivasyon faktörünün işverenin çalışanlara karşı olumsuz tutum ve davranışları, sık yapılan tasarım değişikliği olduğu sonucuna varmıştır.

\section{ARAŞTIRMA}

\subsection{Araştırmanın Amacı}

Çalışma yaşamında bireyi olumsuz etkileyen faktörlerden biri olan tükenmişlik, tükenmişliğe etki eden faktörler literatürde çeşitli meslek grupları için incelenmiştir. Bu çalışmada Türk inşaat sektöründe yer alan mimari tasarım bürolarında çalışan mimarların tükenmişlik düzeylerini etkileyen demotivasyon faktörlerinin incelenmesi amaçlanmıştır. Elde edilen verilerden yola çıkarak mimarların tükenmişlik düzeyleri ve tükenmişlik düzeyine etki eden demotivasyon faktörlerin belirlenmesi, önleyici çözüm önerilerinin sunulması amaçlanmıştır.

Tükenmişlik üzerine yapılan çalışmalar incelendiğinde mimarlık meslek pratiği özelinde az sayıda çalışmanın olduğunu, literatürde bu konuda boşluk bulunduğunu göstermektedir. Çalışma bulguları, literatürdeki bu boşluğu doldurmaya katkı sağlayacağından da önemlidir. Bunun için buraya kadarki bölümde ele alınan kavramsal tanımlar ve değişkenler arasındaki ilişkileri içeren kuramsal bir model geliştirilmiştir. Bu kuramsal model Maslach Tükenmişlik Ölçeği ve Oyedele [14] tarafından geliştirilen demotivasyon faktörlerini içermektedir [13-15]. Kuramsal model tükenmişlik üzerinde demotivasyon faktörlerinin etkisi olduğunu önermektedir. Model önerisi Şekil 1' de gösterilmiştir. Araştırmanın hipotezleri ise Çizelge 1' de belirtilmiştir. Araştırmanın belirtilen amaçlarına ulaşabilmesi için önerilen kuramsal model ampirik olarak incelenmiştir.

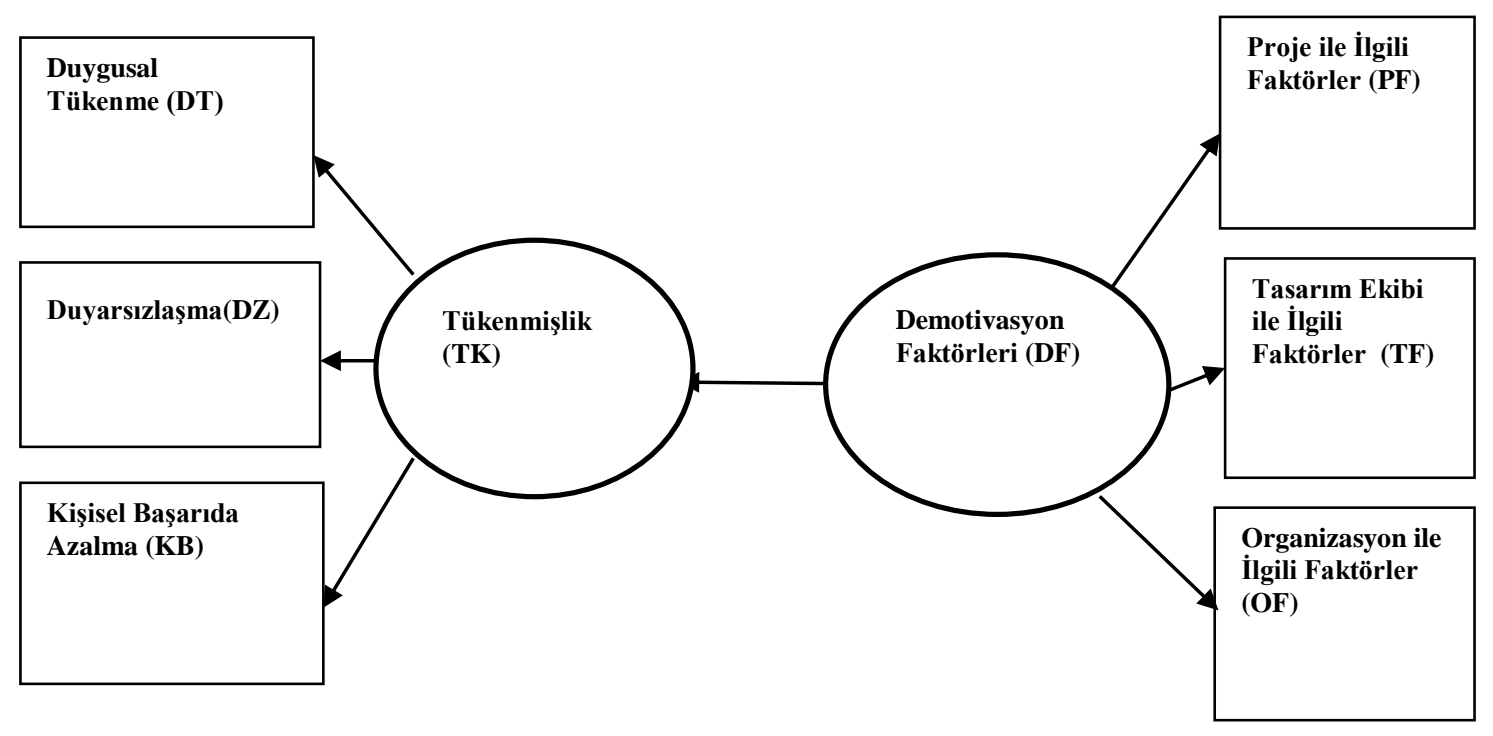

Şekil 1. Tükenmişlik üzerinde demotivasyon faktörlerinin etkisi için kuramsal bir model önerisi 
Çizelge 1. Araştırma hipotezleri

\begin{tabular}{|l|l|}
\hline $\mathrm{H}_{1}$ & Tükenmişlik ile duygusal tükenme arasında olumlu bir ilişki vardır. \\
\hline $\mathrm{H}_{2}$ & Tükenmişlik ile duyarsızlaşma arasında olumlu bir iliş̧i vardır. \\
\hline $\mathrm{H}_{3}$ & Tükenmişlik ile kişisel başarıda azalma arasında olumlu bir ilişki vardır. \\
\hline $\mathrm{H}_{4}$ & Demotivasyon faktörleri ile proje ile ilgili faktörler arasında olumlu bir ilişki vardır. \\
\hline $\mathrm{H}_{5}$ & Demotivasyon faktörleri ile tasarım ile ilgili faktörler arasında olumlu bir ilişki vardır. \\
\hline $\mathrm{H}_{6}$ & Demotivasyon faktörleri ile organizasyon ile ilgili faktörler arasında olumlu bir ilişki vardır. \\
\hline $\mathrm{H}_{7}$ & Tükenmişlik ile demotivasyon faktörleri arasında olumlu bir ilişki vardır. \\
\hline
\end{tabular}

\subsection{Arastırma Yöntemi}

Mimari tasarım bürolarında çalışan mimarların tükenmişlik düzeylerini etkileyen demotivasyon faktörlerini incelemeyi amaçlayan bu çalışmada bir anket çalışması geliştirilmiştir. Mimari tasarım bürolarında uygulanmak üzere geliştirilen anket formunda katılımcıların mesleki tecrübeleri, günlük çalışma saati, çalıştı̆̆ firma yaşı ve büyüklüğ̈̈ açık uçlu soru şeklinde yöneltilmiştir. Tükenmişlik ve demotivasyon faktörleri ise "hiç katılmıorum" ile "tamamen katıliyorum" arasında değişen yedili likert ölçeği kullanılmıştır. Anket formunda katılımcıların tükenmişlik düzeyinin ölçümünde Maslach Tükenmişlik Ölçeği (sorular ve ifadeler) kullanılmıştır $[2,6,7,8,9,10,16,19$, 23]. Anket formunda tükenmişlik üç düzeyde ölçülmüştür. Bunlardan birincisi 7 ifadeden oluşan duygusal tükenme (emotional exhaustion), ikincisi 5 ifadeden oluşan duyarsızlaşma (depersonalization) ve sonuncusu 6 ifadeden oluşan kişisel başarıda azalma (personal accomplishment) alt boyutudur. Demotivasyon faktörlerinin ölçümünde ise Oyedele [14]'in çalışmasında tanımladığı demotivasyon faktörlerinden yararlanılmıştır. Anket formunda yer alan demotivasyon faktörleri ise; 14 ifadeden oluşan proje ile ilgili faktörler, 12 ifadeden oluşan tasarım grubu ile ilgili faktörler, 19 ifadeden oluşan organizasyon ile ilgili faktörleri içermektedir.

Çalışmanın örneklemi, inşaat sektöründe faaliyet gösteren mimari tasarım büroları dikkate alınarak belirlenmiştir.
Araştırmada mimari tasarım bürolarında çalışan mimarlar araştırmanın hedef yanıtlayıcı kitlesi olarak belirlenmiștir. Örneklem ve hedef yanıtlayıcılar belirlendikten sonra, mimari tasarım bürolarında çalıșan mimarlar gerek ziyaret ederek, gerekse e-mail yoluyla temasa geçilip ankete katılmayı kabul edenlerin anket formunu yanıtlaması sağlanmıştır. Anket çalışmasına toplam 156 mimar katılmıştır. Eksik bilgiler nedeniyle 8 anket formu değerlendirme diş1 bırakılmıştır. $\mathrm{Bu}$ nedenle ankete katılan 148 mimari tasarım bürosunda çalışan mimarın yanıtları değerlendirilmiştir. Katılımcıların mesleki tecrübeleri ve günlük çalışma süreleri Şekil 2 ve Şekil 3' te verilmiştir. Katılımcıların mesleki tecrübeleri; \%56' s1 1- 5 y1l, \%18'i 11-25 yı1, \%16' s1 6-10 y1l, \%10' u 26- üzeri yıldır. Günlük çalışma süreleri ise; \%54' ü 9-11 saat, \%35'i 5-8 saat, $\% 11$ 'i 12- üzeri saattir. 12-üzeri günlük çalışma saati aralığı yasal sınırların üzerindedir. Fakat çalışmada bu aralıklar belirlenirken, işyeri dışında çalışma süreleri de dahil edilmiştir.

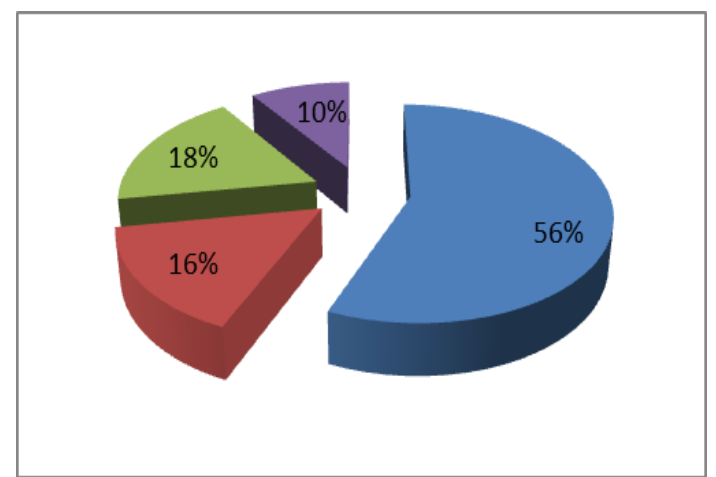

Şekil 2. Katılımcıların mesleki tecrübeleri 


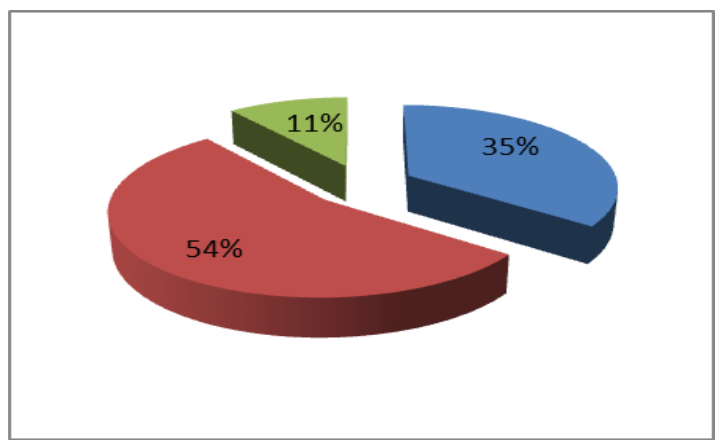

Şekil 3. Katılımcıların günlük çalışma saati

\subsection{Araştırma Sonuçları ve Bulgular}

Çalışma kapsamında değerlendirilen kuramsal modelin istatistiksek olarak incelenmesi için anketlerden elde edilen verilerin güvenilirliğinin test edilmesi gerekmektedir. Bundan dolayı veriler, istatistiksel analiz programına (SPSS 16) girilmiştir. Program ile ankette bulunan soruların güvenilirlik analizi yapılmıştır. güvenilirlik analizi ölçüm konuları içinde yer alan ölçüm sorularının kendi içerisindeki tutarlılığını belirlemek amacıyla Cronbach alfa değerine bakılarak yapılmaktadır.
Güvenilirlik analizi sonucunda 0 ile 1 arasında $(0 \leq \alpha \leq 1)$ değişen değer olan Cronbach alpha değerinde 1'e yakın değerler ölçümün güvenilir olduğunu ifade ederken $0,55^{\prime}$ in altında kalan değerler ise ölçümün güvenilir olmadığını ifade etmektedir [37].

Güvenilirlik analizi sonucu elde edilen çalışma kapsamında incelenen değişkenlerin Cronbach Alpha $(\alpha)$ değerleri Çizelge 2'de verilmiștir. Çalışmada; mimarların tükenmişlik düzeylerini ölçmek için kullanılan, Maslach Tükenmişlik Ölçeği güvenilirlik (Cronbach Alpha) katsayısı 0,764 olarak bulunmuştur.

Duygusal tükenme 0,857, duyarsızlaşma 0,787, kişisel başarıda azalma 0,777 olarak bulunmuştur. Demotivasyon faktörlerine ilişkin güvenilirlik (Cronbach Alpha) katsayısı 0,916, proje ile ilgili kriterler 0,856, tasarım grubu ile ilgili kriterler 0,875 , organizasyon ile ilgili ifadeler 0,912 olarak bulunmuştur. Değişkenlerin Cronbach Alpha $(\alpha)$ değerini karşıladığı görülmüştür (Çizelge 2).

Çizelge 2. Araştırmada kullanılan değişkenlerin ortalamaları $(\mu)$, standart sapmaları $(\sigma)$, Cronbach alfa $(\alpha)$ değerleri, korelasyon analizi sonuçları

\begin{tabular}{|c|c|c|c|c|c|c|c|c|c|c|}
\hline 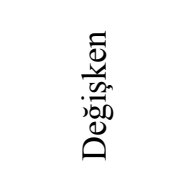 & 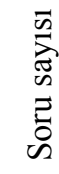 & 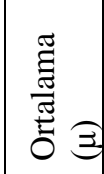 & 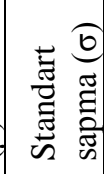 & 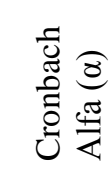 & DT & DZ & KB & $\mathrm{PF}$ & $\mathrm{TF}$ & OF \\
\hline $\begin{array}{c}\text { Firma } \\
\text { yaş1 }\end{array}$ & 1 & & - & - & - & & & & & \\
\hline $\begin{array}{c}\text { Firma } \\
\text { büyüklüğgu }\end{array}$ & 2 & & - & - & - & & & & & \\
\hline DT & 7 & 3,406 & 1,507 & 0,857 & 1 & & & & & \\
\hline DZ & 5 & 2,882 & 1,445 & 0,787 & $0,746 * *$ & 1 & & & & \\
\hline KB & 6 & 2,953 & 1,291 & 0,777 & 0,278 ** & $0,306 * *$ & 1 & & & \\
\hline $\mathrm{PF}$ & 14 & 5,034 & 0,988 & 0,856 & $0,469 * *$ & $0,449 * *$ & 0,098 & 1 & & \\
\hline $\mathrm{TF}$ & 12 & 4,570 & 1,136 & 0,875 & $0,442 * *$ & $0,409 * *$ & 0,036 & $0,451 * *$ & 1 & \\
\hline $\mathrm{OF}$ & 19 & 4,621 & 1,138 & 0,912 & 0,398 ** & $0,433^{* * *}$ & 0,091 & $0,556 * *$ & $0,722 * *$ & 1 \\
\hline
\end{tabular}

$\mathrm{p}^{* * *} \leq 0,001, \mathrm{p}^{* *} \leq 0,01, \mathrm{p}^{*} \leq 0,05$

Çizelge 2 incelendiğinde kategorik olarak ölçülen değişkenler için güvenilirlik analizi kullanılmadığından dolayı çalışma kapsamındaki firma yaşı, firma büyüklüğü değişkenleri (firmada çalışan teknik personel ve idari personel sayısı) için Cronbach Alpha $(\alpha)$ değeri hesaplanmamıştır. 
Çalışmada kullanılan ölçeklerin güvenilirlikleri belirlendikten sonra, tükenmişlik düzeyleri ve demotivasyon faktörleri ortalamalarına değerlendirilip etkinlik düzeyi hesaplanmıștır. Etkinlik düzeyi, genel anlamda davranışların yönelmiş olduğu amaca ulaşma derecesini göstermektedir. Katılımcıların anket formunda yedi noktalı likert ölçeğinde 1 'den 7'ye (1=hiç katılmiyorum, $\quad 7=$ tamamen katıliyorum) derecelendirmeleri sonucu her bir tükenmişlik düzeyi ve demotivasyon faktörü için elde edilen verilerin aritmetik ortalamalarının hesaplanması ile elde edilmiştir. Buna göre; Çizelge 2 incelendiğinde etkinliği en yüksek tükenmişlik düzeyinin duygusal tükenme $(\mu=3,406)$ olarak bulunmuştur. Duyarsızlaşma $(\mu=2,882)$ ve kişisel başarıda azalma $(\mu=2,953)$ düzeylerinin ise birbirine yakın ve düşük değer bulunmuştur. Demotivasyon faktörleri değerlendirildiğinde ise; proje ile ilgili demotivasyon faktörlerinin $(\mu=5,034)$, tasarım grubu ile ilgili faktörlerden $(\mu=4,570)$ ve organizasyon ile ilgili faktörlerden $(\mu=4,621)$ daha etkin olduğu bulunmuștur. $\mathrm{Bu}$ bulgular değerlendirildiğinde mimarların genel olarak tükenmişlik yaşadıklarını, tükenmişliği ağırlıklı olarak duygusal tükenme düzeyinde yaşadıklarını işaret etmektedir.

Değişkenlere ait ortalamaların değerlendirilmesi yapıldıktan sonra değişkenler arası iliş̧i düzeyi korelasyon analizi ile belirlenmiştir. Korelasyon analizi iki değişken arasında ilişki olup olmadığını tespit etmek için kullanılmaktadır. Pearson katsayısı ( $r$ ) ile ifade edilmekte, -1 ile +1 arasında değişmektedir. +1 'e yaklaştıkça pozitif güçlü bir iliş̧kinin varlığından -1'e yaklaş̧ıkça negatif yönde güçlü bir ilişkin varlığından söz edilmektedir. Bu çalışma kapsamında yapılan anketlerden elde edilen veriler değerlendirilerek tükenmişlik düzeyleri ve demotivasyon faktörleri arasındaki ilişkileri araştırmak için korelasyon analizi yapılmıştır. $\mathrm{Bu}$ değişkenler arasındaki ilişkileri araştırmak amacıyla yapılan korelasyon analizi sonuçları Çizelge 2'de verilmiştir. Buna göre; duygusal tükenme ve proje ile ilgili faktörler $(\mathrm{r}=0,469 \mathrm{p} \leq 0,01)$, tasarım ekibi ile ilgili faktörler $(r=0,442 \mathrm{p} \leq 0,01)$, organizasyon ile ilgili faktörler $(\mathrm{r}=0,369 \mathrm{p} \leq 0,01)$ arasında pozitif anlamlı bir ilişki vardır. Bulgular, duyarsılaşma ve proje ile ilgili faktörler $(\mathrm{r}=0,449 \mathrm{p} \leq 0,01)$, tasarım ekibi ile ilgili faktörler $(r=0,409 \mathrm{p} \leq 0,01)$, organizasyon ile ilgili faktörler $(r=0,433 \mathrm{p} \leq 0,01)$ arasında pozitif anlamlı bir ilişkinin varlı̆̆ göstermektedir. Analiz bulgularında kişisel başarıda azalma faktörünün demotivasyon faktörlerinin hiçbiri ile anlamlı bir ilişkisine rastlanmamıştır.

Mimari tasarım bürolarında çalışan mimarların tükenmişlik düzeylerini etkileyen demotivasyon faktörlerinin etkisini incelemek amaciyla geliştirilen kuramsal modelin istatistiksel olarak test etmek için kullanılan yöntem önceki çalışmalar 1şı̆̆ında belirlenmiştir $\left[\begin{array}{ll}16, & 38\end{array}\right]$. Tükenmişlik üzerine etki eden faktörleri inceleyen çalışmalarda en yaygın kullanılan yöntemlerden biri yapısal denklem modeli (YDM) yöntemidir. YDM ikinci nesil çoklu değişken analizi yöntemlerinden biridir. Yapısal denklem modeli (YDM), gözlenebilen ve gizli değişkenler arasındaki ilişkileri test eden bir istatistiksel yöntemdir. Tükenmişlik, demotivasyon gibi doğrudan gözlemlenemeyen değişkenin, bir ya da birden çok değişken aracıllı̆̆ ile (tükenmişlik için; duygusal tükenme, duyarsızlaşma ve kişisel başarı, demotivasyon için; proje ile ilgili faktörler, tasarım ekibi ile ilgili faktörler ve organizasyon ile ilgili faktörler) ölçmeye olanak vermektedir [38, 39]. YDM'in bir diğer özelliği gözlenen değişkenlerdeki olası ölçüm hatalarını (e) modele dahil etmesidir [39].

YDM diğer istatistiksel yöntemlerden (regreasyon, gibi) ayıran en temel özelliği ise, modelde gösterilen bütün ilişkileri tek defada test edebilme olanağı bulunmasıdır. Değişkenleri ölçmekte kullanılan ölçeklerin güvenilirliğini ve değişkenler arasındaki dolaylı veya doğrudan ilişkileri bütünleşik olarak inceleyen nicel bir yöntemdir $[39,40]$. YDM, değişkenler arasındaki dolaylı ve doğrudan ilişkileri, patika katsayıları ( $\beta$ ) ile ifade etmektedir. Modelde yer alan patika katsayılarının hesaplanması sürecinde ise en olası tahmin yöntemini kullanmaktadır [38]. Çalışma kapsamında gerçekleştirilen istatistiksel analizler Amos 20,0 adlı istatistiksel yazılımlar kullanılarak gerçekleştirilmiştir. 
Yapısal denklem modelleme ile ilişkili çok sayıda uyum ve anlamlılık testi geliştirilmiştir [39]. Bunlara genel olarak uyum indeksi uygunluğu (Goodness of Fit Index; GFI) ismi verilmiştir.

GFI değerleri 0 ile 1 arasında değişir ve örneklem genişliğine çok duyarlı olduğu için büyük verilerde daha küçük değerler vermektedir. GFI değeri 1,0’e ne kadar yakın olursa uyum o kadar iyi demektir. AGFI ise örneklem genişliği dikkate alınarak düzeltilmiş olan bir GFI değeridir. Örneklemin büyük olduğu durumlarda AGFI daha temsili bir uyum indeksidir. GIF ve AGFI dişında, gözlenen değişkenler arasındaki hatanın derecesi temelinde geliştirmiş olan mutlak uyum indeksleri de kullanılmaktadır. Bunların başında yaklaşık hataların ortalama karekökü (Root Mean Square Error of Approximation, RMSEA) indeksi gelmektedir. 0,05'e eşit ya da daha küçük olan değerler mükemmel bir uyumu ifade etmektedir.

Çalışmanın bu bölümünde geliştirilen kuramsal model istatistiksel olarak test edilmiştir (Şekil 1). Modelde yer alan demotivasyon faktörlerinin tükenmişlik üzerindeki etkisi yapısal denklem modeli aracılığı ile belirlenmeye çalışılmıştır. Bunu tespit etmek için Amos 20.0 programından faydalanılmıştır. Modelin geçerliliğini ifade eden uyum kriterleri Çizelge 3' de verilmiştir. Modelin uygunluğuna bakıldığında, Araştırma Modeli'ne ait uyum kriter değerleri: $\mathrm{X}^{2} /$ serbestlik derecesi $=$ 1,735; GFI $=0,947 ; \quad$ AGFI $=0,877$; NFI $=0,947$; CFI $=0,976$; ve RMSEA $=0,046$ elde edilmiştir. Araştırma modeli' nin istatistiksel açıdan değerlendirildiğinde güvenilir bir yapısal denklem modeli olduğu sonucu ortaya çıkmaktadır.

Çizelge 3. Yapısal denklem modeli uyum kriterleri [45]

\begin{tabular}{|l|c|c|}
\hline & Araştırma Modeli & Eşik Değer \\
\hline$X^{2} /$ Serbestlik derecesi & 1,735 & $<3,0$ \\
\hline GFI (Uyum İyiliği İndeksi) & 0,947 & $\geq 0,90$ \\
\hline AGFI (Düzeltilmiş Uyum İyiliği İndeksi) & 0,877 & $\geq 0,80$ \\
\hline NFI (Normlaştırılmış Uyum İndeksi) & 0,947 & $\geq 0,90$ \\
\hline CFI (Karşılaştırmalı Uyum İndeksi) & 0,976 & $\geq 0,90$ \\
\hline RMSEA (Yaklaşık Hataların Ortalama Karekökü) & 0,046 & $\leq 0,05$ \\
\hline
\end{tabular}

Çalışmanın bu bölümünde gelitirilen kuramsal model test edilmiştir (Şekil 4). Örnek büyüklüğünü arttırmak amacıyla Amos 20,0 programının Bootstrap algoritması kullanılmıştır. Bootstrap algoritması örnek hacminin yeterli olmadığı durumlarda analiz aşamasında örnek hacmini normal dağılıma göre arttırmak için kullanılmaktadır [örn; 42, 43]. Bu çalışmada Bootstrap sayıs1 500 [örn; 43, 44] olarak seçilmiştir.

Yapısal denklemin değerlendirilmesinde, bağımlı değişkenlerin determinasyon katsayıları $\left(\mathrm{R}^{2}\right)$, güvenilirlik düzeyi (p) ve değişkenler arasındaki ilişkiler için patika katsayıları $(\beta)$ kullanılmaktadır. Yapısal modelin sonuçlarının incelenmesi sonucunda (Çizelge 4), tükenmişliğin açıklanmasında demotivasyon faktörünün etkili olduğunu göstermektedir. Demotivasyon faktörleri tükenmişliği \%84 $\left(\mathrm{R}^{2}=0,840 \mathrm{p} \leq 0,001\right)$ oranında açıklama gücüne sahiptir. Bu sonuçlara ek olarak tükenmişlik değişkeni ile duyarsızlaşma $(\beta=0,870$ $p \leq 0,001)$, duygusal tükenme $(\beta=0,840 p \leq 0,001$, kişisel başarıda azalma $(\beta=0,140 \quad \mathrm{p} \leq 0,05)$ değişkenleri arasındaki patika katsayılarının pozitif anlamlı olduğunu ortaya koymaktadır. Ayrica sonuçlar demotivasyon faktörleri ve proje ile ilgili faktörler $(\beta=0,607, p \leq 0,001)$, tasarım ile ilgili faktörler $(\beta=0,800, p \leq 0,001)$, organizasyon ile ilgili faktörler $(\beta=0,860, \mathrm{p} \leq 0,001)$ arasında pozitif anlamlı bir ilișki var olduğunu göstermektedir. tükenmişlik ile demotivasyon faktörleri arasında $(\beta=0,827, p \leq 0,001)$ olumlu bir ilişki vardır. Elde edilen değerlerin istatistiksel açıdan anlamlı olduğu görülmektedir. Bu sonuçlara göre, önerilen H1, H2, H3, H4, H5, H6, H7 hipotezleri kabul edilmiştir. 
Mimari Tasarım Bürolarında Çalışan Mimarların Mesleki Tükenmişlik Düzeylerini Etkileyen Demotivasyon Faktörleri

Çizelge 4. Araştırma modeline ilişkin $\beta$ katsayıları

\begin{tabular}{|c|c|c|c|c|}
\hline \multicolumn{2}{|c|}{ Değişkenler } & $\beta$ & $\begin{array}{c}\text { Determinasyon } \\
\text { Katsayis1 } \\
\left(\mathrm{R}^{2}\right)\end{array}$ \\
\hline DZ & $\leftarrow$ & TK & $0,870^{* * *}$ & \\
\hline DT & $\leftarrow$ & TK & $0,840^{* * *}$ & \\
\hline KB & $\leftarrow$ & TK & $0,140^{*}$ & \\
\hline PF & $\leftarrow$ & DF & $0,607^{* * *}$ & \\
\hline TF & $\leftarrow$ & DF & $0,800^{* * *}$ & $0,840^{* * *}$ \\
\hline OF & $\leftarrow$ & DF & $0,860^{* * *}$ & \\
\hline TK & $\leftarrow$ & DF & $0,650^{* * *}$ & \\
\hline
\end{tabular}

$\mathrm{p}^{* * *} \leq 0.001, \mathrm{p}^{* *} \leq 0.01, \mathrm{p}^{*} \leq 0.05$

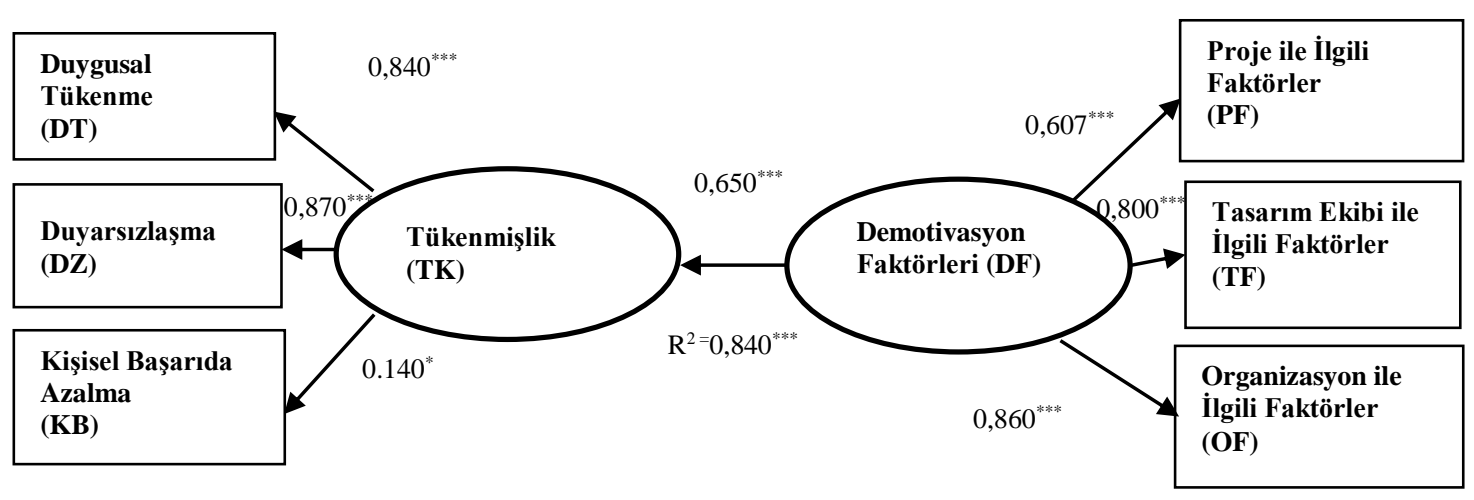

Şekil 4. Tükenmişlik üzerinde demotivasyon faktörlerinin etkisi için yapısal model sonuçları

\section{SONUÇLAR}

$\mathrm{Bu}$ çalışmada inşaat sektöründe faaliyet gösteren mimari tasarım bürolarında çalışan mimarların tükenmişlik düzeyleri üzerinde demotivasyon faktörlerinin etkisi araştırılmıştır. Bunun için, Maslach Tükenmişlik Ölçeği ve Oyedele [14] tarafindan tanımlanan faktörler kullanılarak kuramsal model geliştirilmiştir. Kuramsal modelin analizinde yapısal denklem modeli kullanılmıştır. Yapısal modelin analiz sonuçları Şekil 1'de sunulan kuramsal modeli doğrulamaktadır. $\mathrm{Bu}$ sonuçlar 1şı̆̆ında demotivasyon faktörleri tükenmişlik üzerinde etkili bir faktördür. Bunun nedeni; demotivasyon faktörlerinin mimarlar üzerindeki olumsuz etkilerinin, onların işe karşı ilgilerinin ve coşkularının azalmasına veya tamamen ortadan kalkmasına neden olması, bu durumun zaman içinde tükenmişlik yaşamalarında zemin oluşturmasıdır. Elde edilen bir başka sonuç ise; mimarların duygusal tükenme düzeylerinin, kişisel başarıda azalma ve duyarsızlaşma düzeylerine göre yüksek olduğudur. $\mathrm{Bu}$ bulgu, inşaat sektöründeki birçok katılımcının yer aldığ1 çalışma ortamında mimarların, mesleki gereksinim ve sorumluluklarına, yoğun çalışma temposu ve uzun çalışma saatlerinin eklenmesiyle, duygusal tükenme düzeyinde tükenmişlik yaşadıklarını göstermektedir. Öte yandan bulgular mimarların proje ile ilgili demotivasyon faktörlerinin, tasarım ile ilgili ve organizasyon ile ilgili faktörlere göre daha etkili olduğunu göstermektedir. Yanısıra bulgular, proje ile ilgili faktörler ve duygusal tükenme arasında pozitif bir ilişkinin varlığını 
göstermektedir. Bunun nedeni, mimarlığın proje bazlı bir meslek olması ve projede oluşacak demotive edici bir unsurun doğrudan mimarı etkilemesidir. Elde edilen sonuçlar doğrultusunda mimarların motivasyonlarının sağlanmasında proje ile ilgili taleplerin ve amaçların açık, net ve mantıklı olarak aktarılması gerekmektedir. Sonuç olarak proje ile ilgili yeterli iletişimin kurulması, gerekli imkanların sunulması mimar üzerindeki tükenmişlik gibi olumsuz etkileri azaltacak işe karşı ilgilerini ve coşkularını arttıracaktır.

Bulgular örneklem ile sınırlıdır. $\mathrm{Bu}$ çalışmanın örneklemi genişletilerek inşaat sektöründe faaliyet gösteren diğer meslek profesyonelleri de kapsaması sektör düzeyinde sonuçlara ulaşmayı sağlayacaktır.

\section{KAYNAKLAR}

1. UIA Agreement Text, 1999.

2. Tekin Ö. A., Aydın A., Özmen M., Yaykaşlı M., 2014. Tükenmişlik Sendromu ve Örgütsel Bağl1lık: Su Ürünleri İşletmeleri Üzerinde Bir Araştırma, Dokuz Eylül Üniversitesi Sosyal Bilimler Enstitüsü Dergisi 16, 1,135-158.

3. Leiter, M. P., Maslach, C.. 1988. The Impact of Interpersonal Environment on Burnout and Organizational Commitment, Journal of Organizational Behavior, 9, 4, 297-308.

4. Ardıç K., Polatçı S., 2008. Tükenmişlik Sendromu Akademisyenler Üzerinde bir Uygulama (Gaziosmanpaşa Örneği), Gazi Üniversitesi İktisadi ve İdari Bilimler Fakültesi Dergisi 10, 2, 69-96.

5. Başak O., 2015. Tükenmişlik, Türk Aile Hekimliği Dergisi, 19, 1, 1-2.

6. Maslach, C. ve Jackson, S. E., 1981. The Measurement of Experienced Burnout. Journal of Occupational Behaviour, 2 , 2, 99-113.

7. Maslach, C. ve Zimbardo P. G., 1982. Burnout -The Cost of Caring, Prentice-Hall, Inc., Englewood Cliffs, New Jersey.

8. Ensari, H., Tuzcuoğlu S., 1995. Marmara Üniversitesine Bağlı Fakültelerde Görev Yapan Yönetici ve Öğretim Elemanlarının Meslekten Yılgınlıklarında Kişilik Özelliklerinin Rolü, Öneri Dergisi, 2, 11, 51- 63.
9. Ergin, C., 1995. Akademisyenlerde Tükenmişlik ve Çeşitli Stres Kaynaklarının İncelenmesi, Hacettepe Üniversitesi Edebiyat Fakültesi Dergisi, 12, 1, 37 - 50 .

10. Aslan, D., Kiper N, Karaağaoğlu E., Topal F., Güdük M., Cengiz Ö. S., 2005. Türkiye'de Tabip Odalarına Kayıtlı Olan Bir Grup Hekimde Tükenmişlik Sendromu ve Etkileyen Faktörler, Türkiye Tabip Odaları Birliği Yayınları, Ankara.

11. Rostami Z., Abedi M. R., Schaufeli W. B., 2012. Dose İnterest Predicts Academic Burnout?Interdisciplinary Journal of Contemporary Research in Business, Ijcrb.Webs.Com, 3, 9.

12. Pines, A.M., Nunes, R., 2003. The Relationship Between Career and Couple Burnout: Implications for Career and Couple Counseling, Journal of Employment Counseling, 40, 2, 50-64.

13. Soysal A., 2011. İş Yaşamında Tükenmişlik, Çimento İşveren Dergisi. http://www.ceis.org.tr/dergi/2011kasim/makale 2.pdf, Erişim Tarihi:15.10.2015

14. Oyedele, L. O., 2012. Analysis of Architects' Demotivating Factors in Design Firms, International Journal of Project Management, 31, 342-354.

15. Ünlü T., 2014. Mimarları Etkileyen Demotivasyon Kriterlerinin Analitik Hiyerarşi Proses (AHP) ve Analitik A $\breve{g}$ Prosesi (ANP) ile Ağırlıklandırılması, Gazi Üniversitesi, Fen Bilimleri Enstitüsü, Endüstri Mühendisliği Anabilim Dalı, Yüksek Lisans Tezi, Ankara.

16. Arı G. S. ve Bal E. Ç., 2008. Tükenmişlik Kavramı: Birey ve Örgütler Açısından Önemi, Yönetim ve Ekonomi, 15, 1, Celal Bayar Üniversitesi İ.İ.B.F.

17. Freudenberger, H. J., 1974. Staff Burn-Out, Journal of Social Issues, .30, 1, 159-165.

18. Cherniss, C., 1992. Long-term Consequences of Burnout: An Exploratory Study, Journal of Organizational Behavior, 13, 1-11.

19. Torun A., 1997. Stres ve Tükenmişlik, Endüstri ve Örgüt Psikolojisi, Türk Psikologları ve Kal-der Yayınları, (2.Baskı), Ankara.

20. Sürgevil, O., 2005. Tükenmişlik ve Tükenmişliği Etkileyen Örgütsel Faktörler: Akademik Personel Üzerinde Bir Uygulama, 
Dokuz Eylül Üniversitesi, Sosyal Bilimler Enstitüsü, Yüksek Lisans Tezi, İzmir.

21. Maslach, C., Jackson, S.E., 1981. The Measurement of Experienced Burnout, Journal of Occupational Behaviour, 2, 2, 99-113.

22. Maslach, C., S. E. 1986. Jackson, Maslach Burnout Inventory Manual (2nd Ed.), Palo Alto, Consulting Psychologist Pres.

23. Telli1 E., Ünsar A.S., Oğuzhan A., 2012. Liderlik Davranış Tarzlarının Çalışanların Örgütsel Tükenmişlik ve İşten Ayrılma Eğilimleri Üzerine Etkisi: Konuyla İlgili Bir Uygulama, Electronic Journal of Vocational Colleges, Aralık.

24. Halbesleben, J. R. B., Bowler, W. M., 2007. Emotional Exhaustion and Job Performance: The Mediating Role of Motivation, Journal of Applied Psychology, 92: 93-106.

25. Maslach, C., Leiter P. M., 1997.The Truth About Burnout, Jossey-Bass, San Francisco.

26. Lingard, H., 2003. The impact of Individual and Job Characteristics on 'Burnout' Among Civil Engineers in Australia and Implications for Employee Turnover. Construction Management and Economics, 21, 69-80.

27. Yip B., Rowlinson S., 2009. Job Burnout among Construction Engineers Working within Consulting and Contracting Organizations, Journal of Management in Engineering, 25, 3,122-130.

28. Ng, S.T., Skitmore, M.R., Lam, K.C., Poon, A.W.C., 2004. Demotivating Factors Influencing the Productivity of Civil Engineering Projects, International Journal of Project Management, 22, 139-146.

29. Çelik G.T., 2012. Bağrıaçık R., Oral E.L. Mimarlık Bölümü Öğrencilerinin Akademik Tükenmişliği, Nwsa-Engıneerıng Scıences, 7, 1, 358-367.

30. Çelik G. T., Oral E. L., 2013. Burnout Levels and Personality Traits-The Case of Turkish Architectural Students, Creative Education, 14, 2, 124-131.

31. Steers, R.M., Porter, L.W., 1987. Motivations and Work Behavior, (4th Ed.), New York: McGraw-Hill.

32. Koçel, T., 1999. İşletme Yöneticiliği. (7.Bas.). Beta Basım Yayım Dağıtım A.Ş., 46, İstanbul.
33. Balaban B., 2006. Türk İnşaat Sektöründe Çalışanların Motivasyonu Üzerine Kültürün Etkisi, İstanbul Teknik Üniveristesi, Fen Bilimleri Enstitüsü, Yüksek Lisans Tezi, İstanbul.

34. Maslow A.H., 1970. Motivation and Personality, Harper \&Row Publishers, USA.

35. McClelland, D. C., 1961. The achieving Society, Princeton, NY, Nostland.

36. Doğanlı B., Demirci Ç., 2014. Sağlık Kuruluşu Çalışanlarının Motivasyonlarını Belirleyici Faktörler Üzerine Bir Araştırma, Yönetim ve Ekonomi, 21, 1.

37. Van de Ven, A., Ferry, D., 1979. Measuring and Assessing Organizations, Wiley, NewYork.

38. Yılmaz, V., Varol S., 2015. Hazır Yazılımlar ile Yapısal Eşitlik Modellemesi: Amos, EQS, Lisrel, Dumlupınar Üniversitesi Sosyal Bilimler Dergisi, 44, 28-44.

39. Byrne, B. M., 2010. Structural Equation Modeling with AMOS, Routledge, NewYork.

40. Yeniçeri, T., 2005. Mağaza İmajı ve Mağaza İmajı Boyutları Arasındaki İlişkilerin Yapısal Eşitlik Modeli ile İncelenmesi, Yönetim 16, 52, 30-53.

41. Joreskog, K. G., Sorbom, D., 1993. LISREL 8: Structural Equation Modeling with the SIMPLIS Command Language, Chicago, IL: Scientific Software International.

42. Arbuckle, J. L., 1999. Amos 4.0 Users Guide2, SPSS Inc.

43. Dong, L., Neufeld, D., Higgins, C., 2005. Testing Klein and Sorra's Innovation Implementation Model, Presented at Academy of Management Conference, Hawaii.

44. Bentler, P. M., Chou, C. P., 1987. Practical Issues in Structural Modeling, Sociological Methods and Research, 16, 1, 78-117.

45. Hoyle, R. H., Panter, A. T., 1995. In Structural Equation Modeling: Concepts, Issues and Applications, Sage Publications, London, 158177. 